\title{
Growth and productivity of black spruce (Picea mariana) belonging to the first cohort in stands within and north of the commercial forest in Quebec, Canada
}

\author{
Sergio Rossi*, Hubert MoRIN, Marie-Josée TREMBLAY \\ Département des Sciences Fondamentales, Université du Québec à Chicoutimi, 555 Boulevard de l'Université, Chicoutimi (QC), G7H2B1, Canada
}

(Received 16 December 2009; accepted 16 April 2010)

Keywords:

boreal forest /

forest structure /

old-growth forest /

stem analysis

\begin{abstract}
- The managed area of the North-American boreal forest has been studied extensively. However, because of their inaccessibility, the growth and dynamics of trees at higher latitudes remain unknown, so precluding the possibility of quantifying their productive and economic potential and, if any, their exploitation.

- The aim of this paper was to assess individual growth patterns in dominant black spruces (Picea mariana (Mill.) B.S.P.) belonging to the first cohort and to compare growth dynamics within and north of the commercial forest in Quebec, Canada.

- Compared with stands located on 49th parallel, stands on 51st parallel showed thinner tree rings and $15 \%$ less growth in height, resulting in a $35 \%$ reduction in the stem volume attained at the age of 125 years (170 and $110 \mathrm{dm}^{3}$ for dominant trees in stands within and north of the commercial forest, respectively). At maturity, the annual increment in stem volume in northern stands was $28 \%$ lower than that measured in southern stands.

- These findings represent important information on tree growth in stands of high-latitude boreal forests and should be taken into account when evaluating the profitability of exploiting the remotest Canadian forests. Confirmation by more extensive and spatially-exhaustive inventories is desirable.
\end{abstract}

\section{INTRODUCTION}

The North-American boreal forest has been extensively studied within its major managed area and at the treeline (Johnson, 1992; Lussier et al., 2002; Paquin and Doucet, 1992; Payette, 1996). However, because of their inaccessibility, the studied stands in Canada are sporadic at latitudes between the 51st and 53rd parallels, where the road network is basically inexistent. This drastic lack of study sites has led to a gap in information on growth rates and dynamics of trees in the northern areas of Quebec. Previous work on the ecology and dynamics of the black spruce stands forests in these remote regions have shown how the evolution of the stands without a fire event led to uneven-aged structures and how this dynamics could influence the growth rates of trees, but almost nothing is known about their real productivity (Rossi et al., 2009 a; 2009b). As a result, actually there is no possibility of quantifying the productive and economic potential and, if any, the exploitation of these forest ecosystems (Ministère des Ressources Naturelles, 2000).

* Corresponding author: sergio.rossi@uqac.ca
In Quebec, a northern boundary to the commercial forest has been established between the 51st and 52nd parallels according to criteria of preservation of biodiversity, physical and climatic constraints, forest fire recurrence and productivity (Ministère des Ressources Naturelles, 2000). This boundary drastically reduces the possibility of calculating the productive potential of the boreal forest by excluding roughly $25 \%$ of the area belonging to the black spruce (Picea mariana (Mill.) B.S.P.) - feather moss bioclimatic domain (unpublished data). Nevertheless, as long as the growth rates of these high-latitude forests remain unknown, no economically-advantageous exploitation north of the current managed forest area can be evaluated or considered.

In the northern black spruce forests, the most representative forest formation in the North-American boreal region, the development of an extensive and thick moss layer prevents the establishment of seed-originated seedlings but favours the growth of a dense regeneration produced by natural layering (Rossi et al., 2009a; Viereck and Johnson, 1990). Black spruce is characterized by shade-tolerance, showing growth in as little as $10 \%$ of full light intensity, and by a continuous initiation of adventitious roots following the steady accumulation of organic matter at the base of the stem (Krause and Morin, 


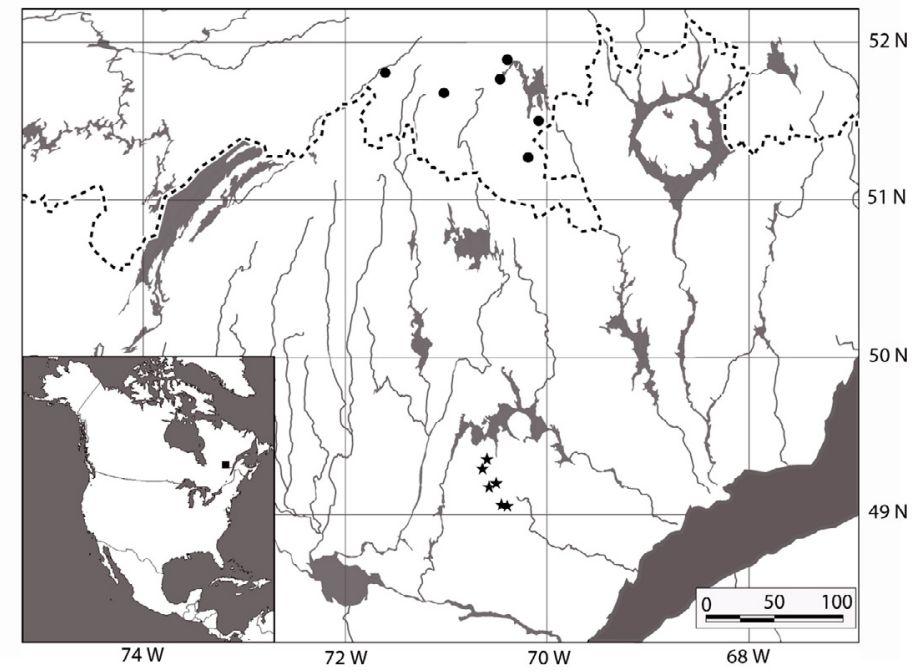

Figure 1. Location of the 12 sampled stands within (stars) and north of (circle) the commercial forest in Quebec, Canada. The thick dotted line corresponds to the boundary of the managed forest area.

2005; Viereck and Johnson, 1990). At lower light intensities, advance regeneration can maintain low production rates by retaining branches and foliage longer and drastically reducing height and diameter growth (Claveau et al., 2002; Takahashi, 1996). These features allow saplings to maintain their presence in the understorey for more than 100 years, by avoiding costs of construction for new tissues, reducing outlay for nonphotosynthetic organs, and waiting with slow growth until a small-scale disturbance occurs to open the canopy (Messier et al., 1999; Rossi et al., 2009a).

So far, the North-American boreal forest has been erroneously associated to even-aged ecosystems with frequent stand-initiating events like fire. However, because of both the survival strategy implemented by the understorey black spruces and the small-scale disturbances that have been demonstrated to occur during the stand lifespan, the formation of multi-cohort structures with uneven-aged age distributions is less infrequent in the boreal forests than previously thought (Fricker et al., 2006; Kneeshaw and Gauthier, 2003; McCarthy, 2001). Trees of uneven-aged stands show onethird-lower growth rates and delayed culminations of mean annual increments in height, diameter and volume following the initial suppression by and competition with the dominant layer (Rossi et al., 2009b). Consequently, the estimated growth rates could provide incorrect information about effective or potential tree performances where tree age is not taken into account or assessed in stands older than 150-200 years, when trees of the secondary cohorts have attained the dominant canopy (Rossi et al., 2009a). The aim of this paper was to assess individual growth patterns in dominant black spruce and to compare growth dynamics within and north of the commercial forest in Quebec, Canada. In this work, stand selection required an assessment of the age structure of each plot in order to restrict the analysis to the trees developed from the seeds germinated after the stand-replacing disturbance and belonging to the first cohort.

\section{MATERIAL AND METHODS}

\subsection{Study area}

The study was conducted at two latitudes (around the 49th and 51st parallels) in the Saguenay-Lac-Saint-Jean region in Quebec, Canada (Fig. 1). The region has a gently rolling topography with hills reaching $500-700 \mathrm{~m}$ a.s.l. on thick and undifferentiated glacial till deposits. This area is part of the black spruce-feather moss bioclimatic domain with a potential vegetation composed mainly of black spruce associated with balsam fir (Abies balsamea (L.) Mill.), jack pine ( $P i$ nus banksiana Lamb.), white spruce (Picea glauca (Moench) Voss), white birch (Betula papyrifera Marsh.) and trembling aspen (Populus tremuloides Michx.) (Robitaille and Saucier, 1998). The meteorological station closest to the study area is located between the two selected latitudes in Bonnard $\left(50^{\circ} 43^{\prime} \mathrm{N}, 71^{\circ} 03^{\prime} \mathrm{W}, 506 \mathrm{~m}\right.$ a.s.l.). The climate is continental, with short, cool summers and long, cold winters with a 30-year mean annual temperature of $-1.8^{\circ} \mathrm{C}$ and total precipitation of $946 \mathrm{~mm}$. About $300 \mathrm{~cm}$ of snow covers the ground from October to May, only disappearing completely in June. Mean temperature exceeds $5{ }^{\circ} \mathrm{C}$ on 138 days per year.

\subsection{Stand selection}

Twelve natural stands were selected around the 49th (southern stands) and 51st parallels (northern stands), within and north of the commercial forest, respectively (Tab. I). Stand selection was performed on inventory maps at the scale 1:50000 (Quebec Ministry of Natural Resources) by using the areas classified as older than $100 \mathrm{y}$, which corresponded to $90 \%$ of the stands of the region. Stands were sorted according to their mapped density and dominant height and were randomly selected from each stratum independently in order to represent the same reported density and height classes between the 
northern and southern stands. As northern stands were inaccessible by road, stand selection was based on the proximity of a lake at least $1 \mathrm{~km}$ in length to permit access by floatplane. In 2006, a preliminary investigation of the age was performed on several trees of different sizes in order to avoid markedly uneven-aged stands. In each selected stand, one square plot of $400 \mathrm{~m}^{2}$ was established and sampled during 2007-2008 (Tab. I). The plot size was twice the area of the larger gaps observed in these forests (McCarthy, 2001). Because of their remote location and the absence of evidence of human impact, the stands were considered to have developed under the influence of natural disturbances only.

\subsection{Data collection}

All living trees with a diameter at breast height (DBH) larger than $9 \mathrm{~cm}$ were cut down and 2-cm-thick discs were collected from the stem base for age determination. In each plot, discs were also collected along the stem of the 5 dominant black spruce trees selected between those with the largest DBH. The sampling heights were $0.6,1.3$ and $2 \mathrm{~m}$ from the collar. Above $2 \mathrm{~m}$, discs were collected at intervals of $2 \mathrm{~m}$ for the remaining length of the stem. In 4 trees ( $6 \%$ of the total), the last 2-3 $\mathrm{m}$ from the top showed forks; in this case, only the longer and upright stem was used for measurements. Discs were air-dried and sanded with progressively finer grade sandpaper. Tree-ring widths were measured to the nearest $0.01 \mathrm{~mm}$ using a Henson measuring system along two-four paths, according to the uniformity of the tree rings on the disc. All ring width series were corrected by cross-dating performed both visually and using the COFECHA computer program (Holmes, 1983). Measurements were averaged for each disc and tree ring.

\subsection{Growth estimation}

The tree height $\left(H_{i j}\right)$ at the age $t_{i j}$ was estimated for the 60 dominant trees using the Carmean (1972) method. After having designated the growth rings at the $i$ th cross section with the subscript $j$ varying from 1 to $r_{i}$ for each tree of age $n$, the assumptions are expressed mathematically by:

$$
H_{i j}=h_{i}+\left[\frac{h_{i}+1-h_{i}}{2\left(r_{i}-r_{i}+1\right)}\right]+(j-1) \cdot\left[\frac{h_{i}+1-h_{i}}{r_{i}-r_{i}+1}\right]
$$

and

$$
t_{i j}=n-r_{i}+j
$$

where $h_{i}$ is the height at the $i$ th cross section, $t_{i j}$ the tree age associated with the $j$ th inner ring at the $i$ th cross section and $r_{i}$ the number of growth rings at the $i$ th cross section. Stem volume was calculated by adding the volume of all tree sections envisaged as truncated cones with the volume $V$ being obtained by the formula:

$$
V=\frac{\pi \cdot l}{3}\left(a^{2}+a b+b^{2}\right)
$$

where $l$ is the height of the truncated cone and $a$ and $b$ the minor and major radius (Van Laar and Akça, 2007).

Multi-cohort stands include trees with slow young growth that is the result of the initial suppression by and competition with the dominant layer. The growth dynamics of these slowgrowing trees affect the accuracy in evaluating the effective growth performance of the stands (Rossi et al., 2009b). Consequently, the growth patterns of trees in the uneven-aged stands were carefully verified and a total of two trees were removed from plot 6 (northern stands) and from plot 3 (southern stands) because they clearly belonged to the secondary cohorts.

\subsection{Curve fitting}

Growths in height and volume were fitted with a sigmoid function using the NLIN procedure (NonLINear regression) and Gauss iterative method in SAS (SAS, 2003) according to Rossi et al. (2009b). For each variable, curve fitting was performed twice, on the observations belonging to the northern and southern stands. The sigmoid function is defined as:

$$
y=A \exp \left[-\mathrm{e}^{-\kappa\left(t-T_{i}\right)}\right]
$$

where $y$ represents stem height or volume and $t$ the tree age. The three parameters are the upper asymptote $A$, the rate of change of the shape $\kappa$ and the $x$-axis placement of the inflection point $T_{i}$. The residuals were regressed onto the partial derivatives with respect to the parameters until the estimates converged. Several possible starting values were specified for each parameter, so that the NLIN procedure evaluated each combination of initial values using the interactions producing the smallest residual sums of squares. Evaluation of the nonlinear regressions was based on statistics for goodness of fit, fitting behaviour and examination of the residuals.

\subsection{Statistical comparisons}

Statistical comparisons between the functions obtained for the northern and southern stands were performed on the curves as a whole and on each estimated parameter.

The fitted curves were compared according to Potvin et al. (1990) using the sums of squares $(S S)$ furnished by the nonlinear regressions and computing $F$-statistics as the ratio between $M S_{o}$ and $M S_{\mathrm{w}}$ :

$$
\begin{gathered}
M S_{\mathrm{w}}=\frac{S S_{\mathrm{w}}}{V_{\mathrm{w}}} \\
M S_{o}=\frac{S S_{\mathrm{t}}-S S_{\mathrm{w}}}{V_{o}}
\end{gathered}
$$

where $S S_{\mathrm{t}}$ is the residual $S S$ prior to grouping (obtained by fitting the function to the complete dataset), and $S S_{\mathrm{W}}$ is the sum of the $S S$ obtained by fitting the function to each group (obtained by fitting the function to the northern and southern stands separately). $V_{\mathrm{w}}$ and $V_{o}$ were calculated with the following:

$$
\begin{aligned}
& V_{\mathrm{w}}=N-g-p_{i} \\
& V_{o}=p_{i}+g-p-1
\end{aligned}
$$


Table I. Location and characteristics (number of trees, dominant height, mean DBH, stand age, density and basal area) of the 12 black spruce plots of $400 \mathrm{~m}^{2}$ within (southern stands) and north of the commercial forest in Quebec, Canada.

\begin{tabular}{|c|c|c|c|c|c|c|c|c|c|c|c|}
\hline \multirow[b]{2}{*}{ Stand } & \multirow[b]{2}{*}{$\begin{array}{c}\text { Stand } \\
\text { number }\end{array}$} & \multirow[b]{2}{*}{ Latitude } & \multirow[b]{2}{*}{ Longitude } & \multirow[b]{2}{*}{$\begin{array}{l}\text { Altitude } \\
\text { (m a.s.1.) }\end{array}$} & \multicolumn{2}{|c|}{ Number of trees in the plot } & \multirow[b]{2}{*}{$\begin{array}{l}\text { Dominant } \\
\text { height }(\mathrm{m})\end{array}$} & \multirow[b]{2}{*}{$\begin{array}{c}\text { Mean DBH } \\
(\mathrm{cm})\end{array}$} & \multirow[b]{2}{*}{$\begin{array}{c}\text { Stand age } \\
\text { (years) }\end{array}$} & \multirow[b]{2}{*}{$\begin{array}{l}\text { Stand density } \\
\left(\text { trees } \mathrm{ha}^{-1}\right)\end{array}$} & \multirow[b]{2}{*}{$\begin{array}{l}\text { Basal area } \\
\left(\mathrm{m}^{2} \mathrm{ha}^{-1}\right)\end{array}$} \\
\hline & & & & & $\begin{array}{l}\text { Black } \\
\text { spruce }\end{array}$ & $\begin{array}{l}\text { Other } \\
\text { species }\end{array}$ & & & & & \\
\hline \multirow{6}{*}{ Northern } & 1 & $51^{\circ} 40^{\prime}$ & $71^{\circ} 01^{\prime}$ & 603 & 37 & 1 & 11.44 & 12.48 & 114 & 950 & 11.91 \\
\hline & 2 & $51^{\circ} 45^{\prime}$ & $70^{\circ} 27^{\prime}$ & 540 & 85 & 5 & 14.98 & 13.06 & 132 & 2250 & 31.17 \\
\hline & 3 & $51^{\circ} 53^{\prime}$ & $70^{\circ} 23^{\prime}$ & 540 & 60 & & 12.49 & 12.4 & 139 & 1500 & 18.68 \\
\hline & 4 & $51^{\circ} 48^{\prime}$ & $71^{\circ} 36^{\prime}$ & 640 & 89 & 7 & 13.7 & 12.91 & 170 & 2400 & 32.63 \\
\hline & 5 & $51^{\circ} 30^{\prime}$ & $70^{\circ} 04^{\prime}$ & 560 & 39 & & 14.41 & 16.52 & 190 & 975 & 21.14 \\
\hline & 6 & $51^{\circ} 16^{\prime}$ & $70^{\circ} 11^{\prime}$ & 535 & 52 & 26 & 19.28 & 16.63 & 213 & 1950 & 46.1 \\
\hline \multirow{6}{*}{ Southern } & 1 & $49^{\circ} 19^{\prime}$ & $70^{\circ} 36^{\prime}$ & 569 & 73 & 7 & 18.58 & 15.66 & 130 & 2000 & 40.21 \\
\hline & 2 & $49^{\circ} 23^{\prime}$ & $70^{\circ} 35^{\prime}$ & 526 & 52 & & 13.33 & 14.59 & 130 & 1300 & 22.68 \\
\hline & 3 & $49^{\circ} 14^{\prime}$ & $70^{\circ} 31^{\prime}$ & 558 & 27 & 1 & 17.47 & 17.15 & 130 & 700 & 18.34 \\
\hline & 4 & $49^{\circ} 04^{\prime}$ & $70^{\circ} 22^{\prime}$ & 567 & 48 & & 11.89 & 12.06 & 131 & 1200 & 14.14 \\
\hline & 5 & $49^{\circ} 04^{\prime}$ & $70^{\circ} 21^{\prime}$ & 522 & 49 & 2 & 17.83 & 15.75 & 134 & 1275 & 24.79 \\
\hline & 6 & $49^{\circ} 12^{\prime}$ & $70^{\circ} 33^{\prime}$ & 609 & 68 & & 14.16 & 13.71 & 138 & 1700 & 26.12 \\
\hline
\end{tabular}

where $N$ is the number of observations of all groups combined, $p$ the number of parameters of the function, $g$ the number of groups and $p i$ the product $g \times p$. The significance level for the $F$-statistics was calculated with $V_{o}$ and $V_{\text {w }}$ degrees of freedom.

Comparisons of the estimated parameters were performed with bootstrapped $t$-tests calculated as:

$$
t=\frac{E_{1}-E_{2}}{\sqrt{s_{1}^{2}+s_{2}^{2}}}
$$

where $E_{i}$ and $s_{i}$ are each of the estimated parameters $A, \beta$ and $\kappa$ and their standard error, respectively (Mencuccini, 2002; Zar, 1999). $t$-statistic was repetitively calculated by randomly resampling the original dataset and estimating 5 and $95 \%$ confidence intervals of the distribution (Efron, 1979). A 10000 times-bootstrapping was performed in order to improve the robustness of results and differences were considered significant $(p<0.05)$ when both confidence intervals were either higher or lower than zero.

\section{RESULTS}

\subsection{Stand description}

A total of 728 trees were measured and harvested for age determination. Plots contained between 28 and 96 trees, which indicated a high density variability, estimated as being from 700 to 2400 trees ha ${ }^{-1}$ (Tab. I). Higher densities were calculated for the northern plots, at 1670 trees $\mathrm{ha}^{-1}$ on average, while 1362 trees $\mathrm{ha}^{-1}$ were estimated in the southern plots. Mean DBH was very similar between southern and northern stands and varied from 12.06 to $17.15 \mathrm{~cm}$, producing a basal area of between 11.91 and $46.10 \mathrm{~m}^{2} \mathrm{ha}^{-1}$. Black spruce formed almost monospecific stands in all plots except in plot 6 of the northern stands, where 23 trees (29.4\% of the total) were balsam fir and 3 were white birch. There were occasional tamarack (Larix laricina) and white birch in plot 1 of the northern stands and plot 1 of the southern stands, respectively, while balsam fir was present in 6 of the 12 plots (Tab. I).
Nine stands showed a clear even-aged structure, with $90 \%$ of tree ages concentrated within 30 years (Fig. 2). Plots 5 and 6 (northern stands) and 3 (southern stands) exhibited a more irregular age distribution. In the northern stands, although most trees in plot 6 revealed an age of 120-140 y, 20\% of trees were older than $180 \mathrm{y}$, which indicated the occurrence of an incomplete stand replacement disturbance.

\subsection{Stem analysis}

On average, tree-ring widths varied between 0.1 and $2.1 \mathrm{~mm}$, with the thinnest tree rings measured at younger and older ages, before 10 and after 100 years (Fig. 3). The widest tree rings were observed at 2-4 $\mathrm{m}$ of height, when trees were 20-30 years old. Wider tree rings were observed in the southern stands at ages ranging between 30 and 90 years and until 6-8 m. At ages over 90 years or heights above $10 \mathrm{~m}$, tree-ring widths in northern and southern stands were similar. The right hand side of Figure 3 shows the number of trees measured at the different heights. Trees in the northern stands attained heights above $4 \mathrm{~m}$ at older ages and the differences gradually increased with height until 12-14 m, when a drastic decrease was observed in the number of trees. A small percentage of the measured trees in the southern stands and only one tree in the northern stands attained a height of $16 \mathrm{~m}$ (Fig. 3).

Growth in height and volume followed an evident sigmoid pattern (Fig. 4). Slow initial increases were observed until 15 and 40-50 years for height and volume, respectively, followed by more rapid growth rates. Growth in volume lacked a plateau at the older tree ages. A heteroscedasticity appeared in all growth curves but was more evident for volume, where proportionally higher increases in data dispersion around the mean values occurred throughout the tree lifespan (Fig. 4). After $125 \mathrm{y}$, abrupt changes in the average and standard deviation were observed in the northern stands, due to the fewer trees reaching these ages that were used for producing the last parts of the curves (data not shown). 


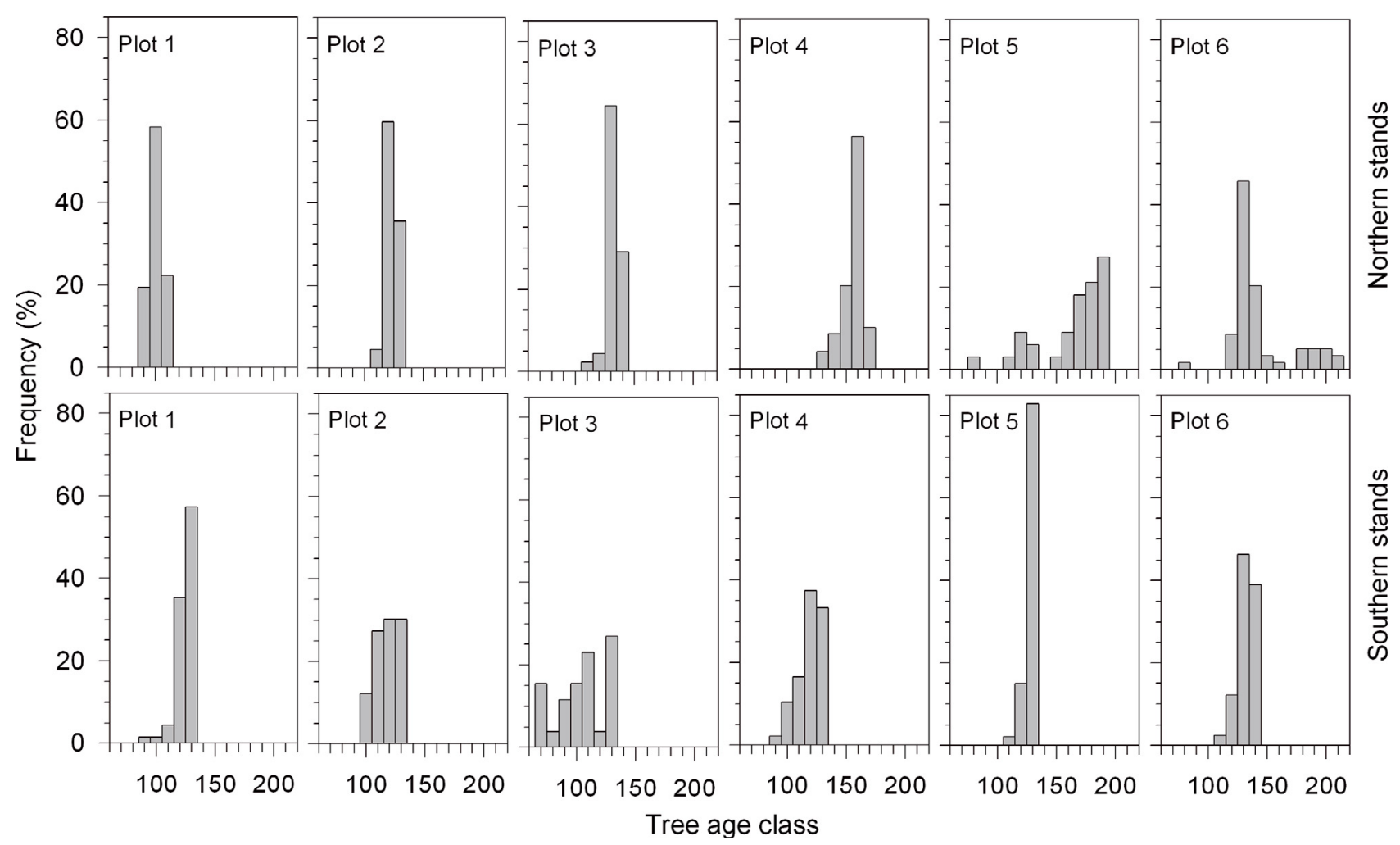

Figure 2. Tree age frequency distribution for the 12 sampled stands within and north of the commercial forest in Quebec, Canada.

\subsection{Growth dynamics in height and volume}

The nonlinear regressions explained a proportion of variation varying between 0.49 and 0.88 , with higher $R^{2}$ observed for the southern stands (Tab. II). Lower $R^{2}$ were obtained for stem volume because of the higher variability in the data (Fig. 4). Standard errors represented $0.7-5.6 \%$ of the parameter values with higher errors estimated for $\kappa$ (Tab. II). The absence of patterns in the distributions of the residuals confirmed the model quality and goodness of fit for all three variables. However, the beginning of the function representing height growth was distant from the origin and predicted values that overestimated the observations until 10 years of age (Fig. 4). Moreover, all functions underestimated growth at tree ages between 115 and 125 years.

Comparisons of the sigmoid functions between the two stand groups produced $F$-statistics of $229.23(p<0.0001)$ and $675.48(p<0.0001)$ for the growth in height and stem volume, respectively. The highly significant probabilities suggested that, overall, the growth curves differed statistically between the northern and southern stands. The functions exhibited very similar patterns of growth for both height and stem volume with similar values estimated for the parameters $\mathrm{K}$ and $T_{i}$ (bootstrapped $t$-tests in Fig. 5). The bootstrapped $t$ tests showed statistically different asymptotes $A$, which indicated that trees in the southern stands were taller (16.7 versus $14.3 \mathrm{~m}$ ) and attained higher stem volume (242.6 versus $143.7 \mathrm{dm}^{3}$ ) than trees in the northern stands (Tab. II).
Annual increments in height culminated between 41 and 44 years, while later culminations were observed for stem volume at 73-79 years of age ( $T_{i}$ parameter in Tab. II and Fig. 5). The patterns of the annual increments for northern and southern stands were clearly synchronous and similar during the first development stages. Close to and after the culmination of the annual increments, higher differences in growth vigour appeared, with increments in the northern stands at the time of culmination being 83 and $72 \%$ of those in the southern stands for height and stem volume, respectively. Although annual increments in height converged towards similar values at older tree ages ( $\left.3-4 \mathrm{~cm}_{\text {year }}{ }^{-1}\right)$, at 125 years the northern stands still showed 57\% lower growth rates in stem volume than those of the southern stands.

\section{DISCUSSION}

Increasing interest in exploiting the forests of the northern boreal ecosystems requires more knowledge about tree growth at these latitudes. This paper compared individual growth of black spruce from stands within and north of the commercial forest in Quebec. Within $2^{\circ}$ of latitude between the 49th and 51 st parallels, thinner tree rings and $15 \%$ less growth in height were observed for the northern stands, compared with the southern ones. This reduction in height and radius resulted in a 35\% lower stem volume attained at the age of 125 years $(170$ and $110 \mathrm{dm}^{3}$ for dominant trees of stands within and north of the commercial forest, respectively). At maturity, the annual 


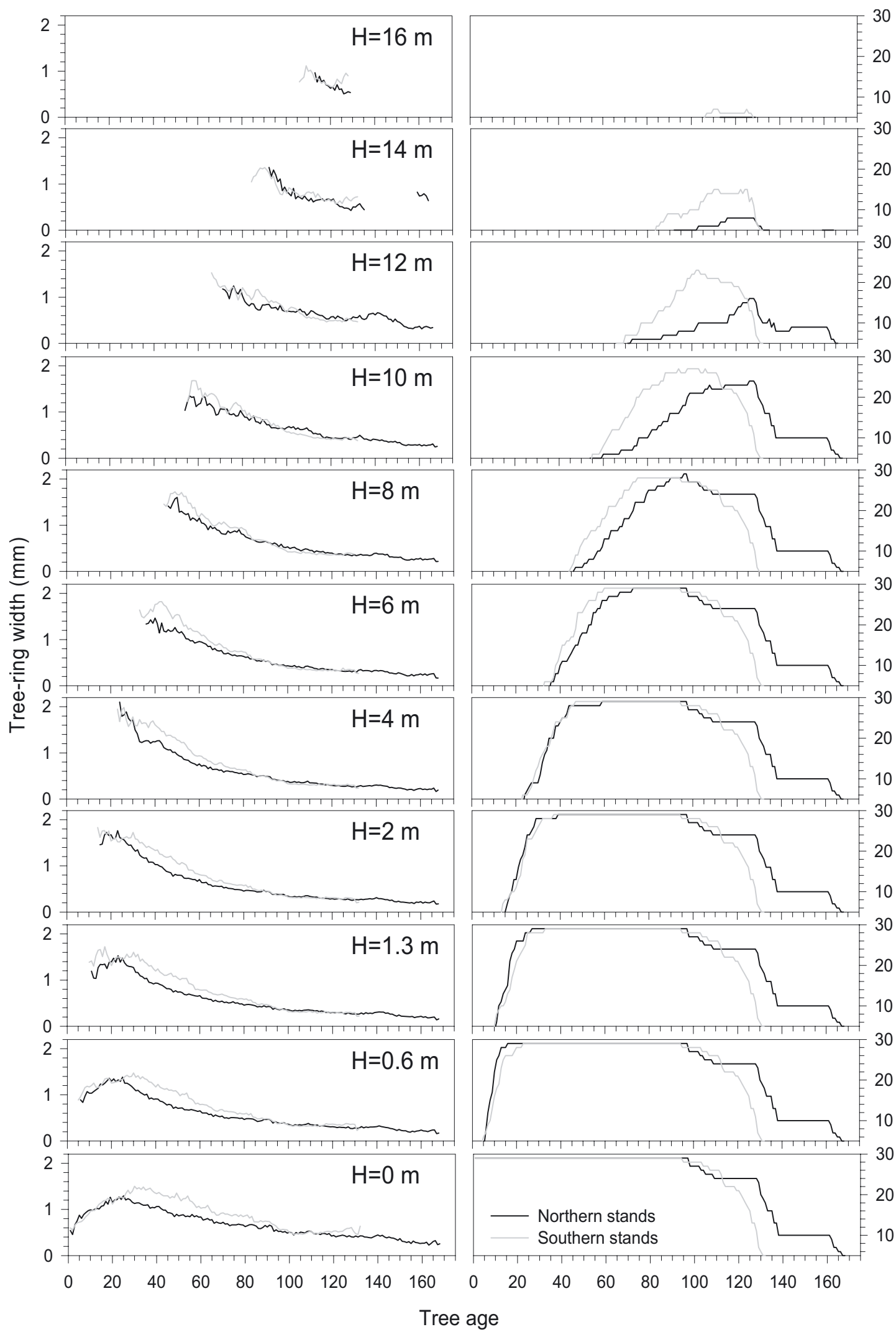

Figure 3. Average tree-ring widths measured along the radius on sections collected at different heights $(H, m)$ along the stem of black spruce trees from stands within and north of the commercial forest in Quebec, Canada. The number of measured trees is also reported. 

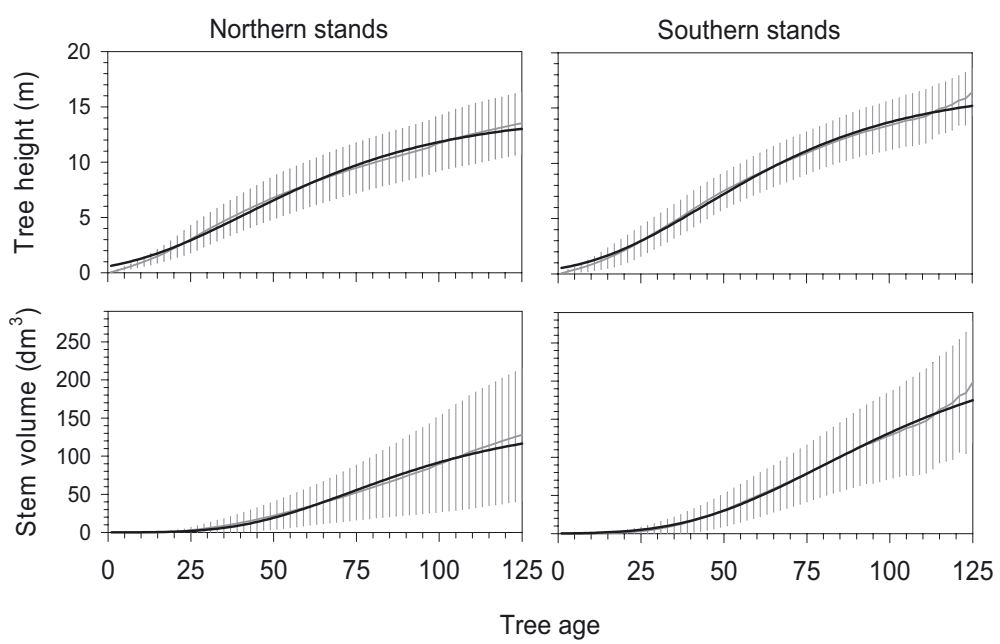

Figure 4. Individual growth in height and stem volume (grey line) and fitted sigmoid functions (black line) for black spruce trees from 12 stands within and north of the commercial forest in Quebec, Canada. Vertical bars correspond to the standard deviation between trees.

Table II. Parameters of the sigmoid function ( $A$, upper asymptote; $\kappa$, rate of change; $T_{i}$, $\mathrm{x}$-axis placement of the inflection point) and $\mathrm{R}^{2}$ for models fitted by nonlinear regressions with tree height and stem volume of black spruce in stands within and north of the commercial forest in Quebec, Canada. Values in parentheses represent the standard error of the estimated parameters.

\begin{tabular}{cccccc}
\hline Variable & Stand & $A$ & $\kappa\left(10^{-2}\right)$ & $T_{i}$ & $R^{2}$ \\
\hline \multirow{2}{*}{ Height } & Northern & $14.30(0.11)$ & $2.82(0.06)$ & $41.30(0.47)$ & 0.82 \\
& Southern & $16.73(0.16)$ & $2.88(0.06)$ & $44.02(0.49)$ & 0.88 \\
\cline { 2 - 6 } Volume & Northern & $143.70(4.05)$ & $3.00(0.17)$ & $73.28(1.37)$ & 0.49 \\
& Southern & $242.62(12.18)$ & $2.46(0.14)$ & $79.86(2.41)$ & 0.66 \\
\hline
\end{tabular}
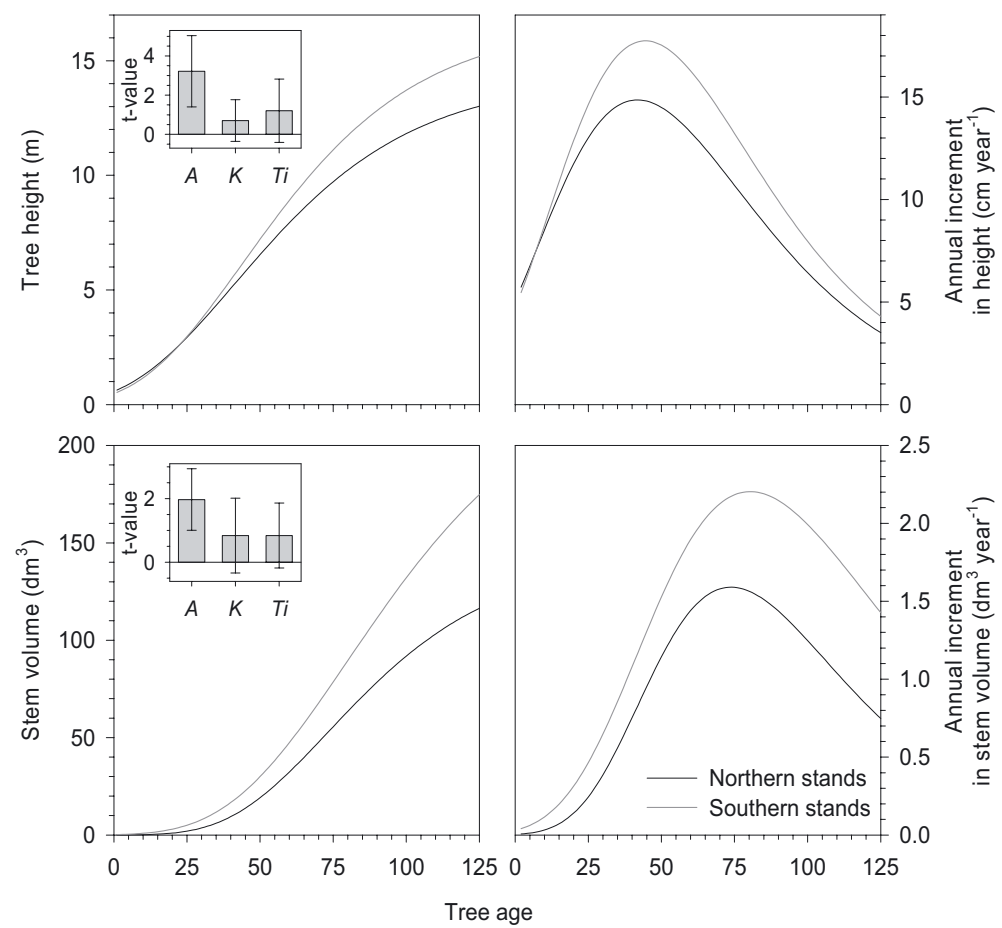

Figure 5. Sigmoid functions representing mean individual growth in height and stem volume and corresponding current annual increments for black spruce in 12 stands within and north of the commercial forest in Quebec, Canada. The enclosed vertical bars represent average and 5 and $95 \%$ confidence intervals of the bootstrapped $t$-statistics calculated by 10000 replications. $t$-test is considered significant when both confidence intervals are either higher or lower than zero. 
increment in stem volume was strongly affected by latitude, with $28 \%$ lower growth rates measured in the northern stands at 75 years, compared with the southern stands. Although a decrease in height and wood production was expected with latitude (Ekö et al., 2008; Moles et al., 2009), to our knowledge this is the first time that individual growth patterns are compared between different latitudes in pristine stands of the Canadian boreal forest after having assessed the age structure.

Similar radial and height increments between stands within and north of the commercial forest were observed before 2530 years, when trees were less than $4 \mathrm{~m}$ tall on average. At that height, the crown is still not closely coupled to the prevailing atmospheric conditions because small trees can strongly modify their microclimate. During the harsher season, they remain protected below the deep snow cover, while in spring, even at low air temperatures, the low stature allows higher heat accumulations within the canopy and an early resumption of growth (Körner, 2003). Moreover, tree-ring widths in the tallest trees were similar between northern and southern stands. Nevertheless, only the individuals growing in the most favourable locations or fertile stands, were able to attain heights over $12 \mathrm{~m}$. Consequently, the major differences in tree growth occurred during and after the culmination of the increments in diameter and height, at ages comprised between 30 and 80 years. After the culmination and until 125 years, stem volume increments in the stands located within the commercial forest maintained higher values than those observed in the northern stands.

Assessment of the age structure in each stand allowed more precise estimations of the growth potentials of the trees to be attained. The investigations performed on specimens of evenaged stands or belonging to the first cohort developing after stand initiation ensured that trees had not experienced any suppressing periods during the juvenile stages. In the past, uniform, single-cohort stands have been associated with the boreal forest. However, the frequent occurrence of multi-cohort stands originated by smaller-scale disturbances in these northern ecosystems has been largely demonstrated (Kuuluvainen, 2009; McCarthy, 2001; Shorohova et al., 2009), with trees of secondary cohorts showing lower and slower growth increments (Rossi et al., 2009a). In this work, the accuracy of our results was also confirmed by the similar dynamics of growth in height and stem volume, represented by the shape and placement parameters of the fitted sigmoid curves (Fig. 5).

North of the 49th parallel, reductions in radial and height growth of black spruce with latitude are associated with smaller tracheids and higher amounts of latewood (St-Germain and Krause, 2008). Latewood proportion explains up to $73 \%$ of variation in wood density and is decisive in determining the intrinsic resistance properties of wood and, consequently, its quality and utilisation (Hannrup et al., 2001). Despite the lower growth in volume, the potentially higher quality of the wood harvested from the stands north of the commercial boundary suggests higher-priced timber products. This could allow a sufficient profit margin to be maintained when exploiting the remotest forested areas of Northern Canada.

The sigmoid function used in this work represented adequately the growth pattern in height and volume. However, a reduced quality of fitting appeared at the beginning and ending of the curves, at ages lower than 10 years for height growth, and between 115 and 125 years for both height and volume growth. Although fitting of cumulative growth data could be realized using a more flexible interpolated spline, the explicitly-defined models such us the sigmoid functions better describe growth through a functional approach. Even if statistically comparable descriptions can be achieved by either model, the polynomial-based equations are devoid of any biological interpretation (Zeide, 1993). Moreover, every parameter of the sigmoid functions can be separately analyzed or compared (Mencuccini, 2002; Rossi et al., 2006). In this work, two statistical approaches with different levels of definition were used for comparing growth between stands within and north of the commercial forest in Quebec. The first one evaluated the differences in the growth patterns (Potvin et al., 1990), while the second one investigated which parameters better define these differences (Mencuccini, 2002). Results clearly demonstrated that the differences lay essentially on the intensity of growth (parameter $A$ in Fig. 5) rather than on the interannual dynamics of growth (parameters $\kappa$ and $T_{i}$ in Fig. 5).

\section{CONCLUSION}

The northern boundary to the commercial forest has considerably reduced the wood stocks of the Quebec resources in order to maintain sustainable long-term forest exploitation. However, this boundary was established despite very little being known about the dynamics and productivity of the remote and inaccessible northern stands. This investigation analysed the dynamics of individual tree growth belonging to the firstcohort and compared stands located within and north of the commercial forest. Our findings showed a significant decrease in height and radius increment of the dominant trees, which led to $35 \%$ reductions in the stem volume attained at the age of 125 years. Although confirmation by more extensive and spatially-exhaustive inventories is desirable, these preliminary but exclusive results should be seriously taken into account when evaluating the profitability of exploiting the northern forests of Canada.

Acknowledgements: This work was funded by Consortium de Recherche sur la Forêt Boréale Commerciale, Fonds de Recherche sur la Nature et les Technologies du Québec and Conseil de Recherches en Sciences Naturelles et en Génie du Canada. The authors thank L. Blais, J.-G. Girard, G. Savard and P. Tremblay for technical support, D. Mailly for his suggestions during data analysis and A. Garside for checking the English text.

\section{REFERENCES}

Carmean W.H., 1972. Site index curves for upland oaks in the Central States. For. Sci. 18: 109-120.

Claveau Y., Messier C., Comeau P.G., and Coates K.D., 2002. Growth and crown morphological responses of boreal conifer seedlings and saplings with contrasting shade tolerance to a gradient of light and height. Can. J. For. Res. 32: 458-468. 
Efron B., 1979. Bootstrap methods: another look at the jackknife. Ann. Stat. 7: 1-26.

Ekö P.M., Johansson U., Petersson N., Bergqvist J., Elfving B., and Frisk J., 2008. Current growth differences of Norway spruce (Picea abies), Scots pine (Pinus sylvestris) and birch (Betula pendula and Betula pubescens) in different regions in Sweden. Scand. J. For. Res. 23: 307-318.

Fricker J.M., Chen H.Y.H., and Wang J.R., 2006. Stand age structural dynamics of North American boreal forests and implications for forest management. Int. For. Rev. 8: 395-405.

Hannrup B., Danell Ö., Ekberg I., and Moëll M., 2001. Relationships between wood density and tracheid dimensions in Pinus sylvestris L. Wood Fiber Sci. 33: 173-181.

Holmes R.L., 1983. Computer-assisted quality control in tree-ring dating measurement. Tree-Ring Bull. 43: 69-78.

Johnson E.A., 1992. Fire and vegetation dynamics: studies from the North American boreal forest, Cambridge University Press, UK.

Kneeshaw D., and Gauthier S., 2003. Old growth in the boreal forest: a dynamic perspective at the stand and landscape level. Environ. Rev. 11: S99-S114.

Körner C., 2003. Alpine plant life: functional plant ecology of high mountain ecosystems, Springer-Verlag, Berlin.

Krause C., and Morin H., 2005. Adventive-root development in mature black spruce and balsam fir in the boreal forests of Quebec, Canada. Can. J. For. Res. 35: 2642-2654.

Kuuluvainen T., 2009. Forest management and biodiversity conservation based on natural ecosystem dynamics in Northern Europe: the complexity challenge. Ambio 38: 309-315.

Lussier J.-M., Morin H., and Gagnon R., 2002. Mortality in black spruce stands of fire or clear-cut origin. Can. J. For. Res. 32: 539-547.

McCarthy J., 2001. Gap dynamics of forest trees: a review with particular attention to boreal forests. Environ. Rev. 9: 1-59.

Mencuccini M., 2002. Hydraulic constraints in the functional scaling of trees. Tree Physiol. 22: 553-565.

Messier C., Doucet R., Ruel J.-C., Claveau Y., Kelly C., and Lechowicz M.J., 1999. Functional ecology of advance regeneration in relation to light in boreal forests. Can. J. For. Res. 29: 812-823.

Ministère des Ressources Naturelles, 2000. La limite nordique des forêts attribuables. Rapport final du comité, Gouvernement du Québec.

Moles A.T., Warton D.I., Warman L., Swenson N.G., S.W. L., Zanne A.E., Pitman A., Hemmings F.A., and Leishman M.R., 2009. Global patterns in plant height. J. Ecol. 97: 923-932.
Paquin R., and Doucet R., 1992. Croissance en hauteur à long terme de la régénération préétablie dans des pessières noires boréales régénérées par marcottage, au Québec. Can. J. For. Res. 22: 613-621.

Payette S., Delwaide A., Morneau C., and Lavoie C., 1996. Patterns of tree stem decline along a snow-drift gradient at treeline: a case study using stem analysis. Can. J. Bot. 74: 1671-1683.

Potvin C., Lechowicz M.J., and Tardif S., 1990. The statistical analysis of ecophysiological response curves obtained from experiments involving repeated measures. Ecology 71: 1389-1400.

Robitaille A., and Saucier J.-P., 1998. Paysages régionaux du Québec méridional, Les Publications du Québec, Québec.

Rossi S., Deslauriers A., Anfodillo T., Morin H., Saracino A., Motta R., and Borghetti M., 2006. Conifers in cold environments synchronize maximum growth rate of tree-ring formation with day length. New Phytol. 170: 301-310.

Rossi S., Tremblay M.-J., Morin H., and Levasseur V., 2009a. Stand structure and dynamics of Picea mariana on the northern border of the natural closed boreal forest in Quebec, Canada. Can. J. For. Res. 39: 2307-2318.

Rossi S., Tremblay M.-J., Morin H., and Savard G., 2009b. Growth and productivity of black spruce in even- and uneven-aged stands at the limit of the closed boreal forest. For. Ecol. Manage. 258: 2153-2161.

SAS, 2003. SAS System, version 9.1.3 SAS Institute Inc., Cary, N.C.

Shorohova E., Kuuluvainen T., Kangur A., and Jõgiste K., 2009. Natural stand structures, disturbance regimes and successional dynamics in the Eurasian boreal forests: a review with special reference to Russian studies. Ann. For. Sci. 66: 201.

St-Germain J.-L., and Krause C., 2008. Latitudinal variation in tree-ring and wood cell characteristics of Picea mariana across the continuous boreal forest in Quebec. Can. J. For. Res. 38: 1397-1405.

Takahashi K., 1996. Plastic response of crown architecture to crowding in understorey trees of two co-dominating conifers. Ann. Bot. 77: $159-164$.

Van Laar A., and Akça A., 2007. Forest mensuration, Springer, Dordrecht, The Netherlands.

Viereck L.A., and Johnson W.F., 1990. Picea mariana (Mill.) B.S.P., black spruce. In: Burns R.M., Honkala B.H. (Eds.), Silvics of North America, U.S. Department of Agriculture, Forest Service, Washington, D.C.

Zar J.H., 1999. Biostatistical Analysis, Upper Saddle River, New Jersey. Zeide B., 1993. Analysis of growth equations. For. Sci. 39: 594-616. 